\title{
The Impact of Human Resource Planning (HRP) in Achieving the Strategic Goal of the Firm With the Moderating Role of Organizational Innovation
}

\author{
Jehad Bani Hani, University of Jeddah, Saudi Arabia
}

\begin{abstract}
The aim of this study is to examine the impact of human resource planning (HRP) in achieving the strategic goal of the firm and organizational productivity. Structural equation modeling (SEM) approach is used to investigate causal relationship among exogenous and endogenous variables. Findings indicate that underpinned factors like talent management, succession planning, job analysis, staffing plan, and career development have showed positive impact to predict strategic goals of the firm. The interaction effect between achieving the strategic goal and organizational innovation is found significant, and it is confirmed that the positive relationship between achieving the strategic goal of the firm and organizational productivity will be stronger when organizational innovation is higher. Effect size analysis $[(\mathrm{f})]^{\wedge} 2$ indicates that employee creativity has the highest effect size in achieving strategic goal of the firm. Finally, the current study contributes to theory and practice while showing the importance of human resource planning in predicting organizational productivity.
\end{abstract}

\section{KEYWORDS}

Employee Creativity, Human Resource Planning, Organizational Innovation, Organizational Productivity, Strategic Goal of Firm, Structural Equation Modeling

\section{INTRODUCTION}

The mobilization of human resource is increasing day by day and it has become the biggest challenge for organizations. Organizations need to make continuous effort to survive in turbulent business environment. The role of human resource planning (HRP) which includes factors like talent management, succession planning, staffing plan, job analysis and career development have been identified crucial in achieving organizational goals and productivity (Deci \& Ryan, 1985, 2000; Dewett, 2007; Hirst, Van Dick, \& Van Knippenberg, 2009; Martín Cruz, Martín Pérez, \& Trevilla Cantero, 2009; Vroom, 1964; S. Wang \& Noe, 2010; Zhou \& George, 2003). The talent management practices wherein organizations recognize scientific knowledge among employees and augment their skills to achieve strategic goals of the firm (Chakraborty \& Biswas, 2019; Mardani, Nikoosokhan, Moradi, \& Doustar, 2018; C. L. Wang \& Ahmed, 2004). In addition to that talent management contributes by coaching and mentoring employee and had confirmed positive impact in organizational productivity (Mohammed, 2016; Mwanzi, Wamitu, \& Kiama, 2017). 
Succession planning activities includes comprehensive strategic plan that employee adopt and later apply to solve critical problem which ultimately help organizations to achieve firm goals (Kiumarsi, Isa, Jayaraman, Amran, \& Hashemi, 2020; Seniwoliba, 2015). The use of staffing plan drives efficient workforce which impart values in achieving sustainable goals of the organizations (Aslam, Aslam, Ali, \& Habib, 2013; Hurley \& Choudhary, 2016; Omidi \& Shafiee, 2018; Powell, 2012; Robson, 2013). The job analysis and design process provide autonomy, variety and task significance to employee in order to achieve firm performance (Belias \& Sklikas, 2013; Tufail, Bashir, \& Shoukat, 2017). Authors like to Belias and Sklikas (2013) stated that less is discussed about human resource planning and achieving strategic goal of the firm. Therefore, the current study fills the research gap by studying talent management, staffing plan, succession plan and job analysis and design in the context of aching strategic goals of the firms.

The role of career development and employee creativity has been identified crucial. Career planning activities synthesize organizational needs and encourage employees to achieve organizational goals cost effectively. It is also argued that career planning development provide clear guideline to employees helps them to accomplish tasks timely (Jameendar, 2014). Similarly, author like Zhou and George (2003) asserted that employee creativity introduce novelty in business which in turn enhance business performance. Although the focus of this study was to investigate employee commitment towards achieving strategic goal of firm and organizational productivity, it added organizational innovation in the research model. Organization innovation is identified as organization efforts to bring and adopt new and unique methods to carry on daily business activities (Ha \& Lo, 2018; Hurley \& Choudhary, 2016; Irfan \& Marzuki, 2018; Jimenez-Jimenez, Sanz Valle, \& Hernandez-Espallardo, 2008; Okoye, 2007; Powell, 2012; Robson, 2013; Uddin, Luva, \& Hossian, 2013; Uzkurt, Kumar, Semih Kimzan, \& Eminoğlu, 2013). Thereby, the role of organizational innovation is studied as moderator between achieving strategic goal of the firm and organisational productivity. This study is significant as it investigate firm's strategic goal and organizational productivity with an amalgamated model which includes direct and moderating effects of the constructs.

\section{LITERATURE REVIEW}

\subsection{Talent Management}

Talent management concept is used to identify employee competencies within organization to survive in dynamic business environment which in turn impact on organizational performance (Chakraborty \& Biswas, 2019; Mohammed, 2016; Okoye, 2007; Saviour, Kofi, Yao, \& Kafui, 2017). According to Abazeed (2018) postulated that talent management helps to recognize scientific knowledge among employees and augment their skills using acquired knowledge. In organization talent management contributes by coaching and mentoring employee and had revealed positive impact in achieving organization strategic goals (Mohammed, 2016; Mwanzi et al., 2017; Sareen \& Mishra, 2016). The adoption of talent management strategies had made employees proactive and enthusiastic towards achieving organizational goals (Naeiji \& Siadat, 2018; Pasha \& Ahmed, 2017). An integrated model with combination of talent and business strategies ensures consistency in achieving firm objectives (Lyria, 2015). Earlier studies have confirmed that an integrated talent management model instigate employee to achieve individual and corporate goals proactively (Abazeed, 2018; Mangusho, Murei, \& Nelima, 2015; Mwanzi et al., 2017; Pasha \& Ahmed, 2017). Following above arguments and back up by previous studies conducted by Abazeed (2018); Mangusho et al. (2015); Mwanzi et al. (2017); Pasha and Ahmed (2017); Sareen and Mishra (2016) talent management is anticipated as:

H1: Talent management has positive influence on achieving strategic goal of firm. 


\subsection{Succession Plan}

Succession plan is a systematic process to produce new successor or personnel with right knowledge and skills. The succession plan prevents disarrays in business operations and enable employees to handle business needs and demands successfully (Adewale, Abolaji, \& Kolade, 2011). On the flip side lacking succession plan leads to failure in achieving organizational goals (Maimone \& Sinclair, 2014; Mittal \& Dhar, 2015; Omidi \& Shafiee, 2018; Sternberg \& Lubart, 1999; S. Wang \& Noe, 2010). Therefore, examining the role of succession plan in determining strategic goal of the firm is imperative. The importance of succession planning is highlighted in previous studies (Adewale et al., 2011; Das, 2013; Komora, Guyo, \& Odhiambo, 2015; Seniwoliba, 2015). Use of secession planning strategies helps organizations to move propitiously in dynamic business environment (Adewale et al., 2011; Galli, 2018). Another study conducted by Seniwoliba (2015) highlighted that succession plan ensure employee responsibilities, proficiencies and coordination to attain organization strategic goals. In other words secession plan is an effort to achieve organizational goals with adequate personnel skills and experiences (Adewale et al., 2011; Anilkumar \& Sridharan, 2019; Das, 2013; Seniwoliba, 2015). Earlier studies had confirmed that succession plan assess necessary skills and experience of the personnel which in turn helps them to achieve firm goals (Adewale et al., 2011; Das, 2013; Komaki, 2003; Komora et al., 2015; Seniwoliba, 2015; Vroom, 1964). Thus, we advance the following hypothesis:

H2: Succession plan has positive influence on achieving strategic goal of firm.

\subsection{Staffing Plan}

The term staffing is used in organizations to hire personnel by looking at their knowledge, skills and competencies that contribute to firm and add values. An adequate staffing helps organization to deploy employee services according to their needs (Chakraborty \& Biswas, 2019). The importance of staffing is highlighted by earlier researchers Chakraborty and Biswas (2019); Maih (2015); Saddam and Mansor (2015) and concluded that right staffing augments organizational policies and programs and promote firm purpose. Staffing strategies integral part of the human resource management and fetch efficient workforce to achieve firm goals and objective (Schroeder, 2012). The use of staffing plan drives efficient workforce which impart values in achieving sustainable goals of the organizations (Aslam et al., 2013). According to Chakraborty and Biswas (2019) adroit quality of the employee is noteworthy during staffing and played vital role in achieving strategic business goals. Earlier studies had confirmed that adequate staffing strategies augment organizational process and programs and encourage employees to achieve firms goals (Aslam et al., 2013; Chakraborty \& Biswas, 2019; Ekwoaba, Ikeije, \& Ufoma, 2015; Maih, 2015; Saddam \& Mansor, 2015; Saviour et al., 2017; Schroeder, 2012). Hence, we hypothesized staffing plan as:

H3: Staffing plan has positive influence on achieving strategic goal of firm.

\subsection{Job Analysis and Design}

Job analysis and design process includes the identification of employee skills, polishing and design their skills according to job need and provide them equal opportunities to participate in firm decision making (Belias \& Sklikas, 2013). Job analysis and design is essential and consider an important factor in human resource management. The job analysis and design process provide autonomy, variety and task significance to employee in order to achieve firm performance (Belias \& Sklikas, 2013; Tufail et al., 2017). Job analysis is a win-win situation wherein employees and organizations both get equal opportunities. For organizations job analysis gives clear work directions to employee to execute firm's goals and strategic objectives (Suthar, Chakravarthi, \& Pradhan, 2014). Earlier studies had confirmed 
positive impact of employee job analysis and design on firm strategic goals and performance (Belias \& Sklikas, 2013; Suthar et al., 2014; Tufail et al., 2017). Job analysis motivate employees to achieve desired firm goals cost effectively (Tufail et al., 2017). Therefore and supporting by previous literature Belias and Sklikas (2013); Ehsan (2018); Mardani et al. (2018); Okoye (2007); Sharif and Karim (2017); Suthar et al. (2014); Tufail et al. (2017); C. L. Wang and Ahmed (2004), the job analysis and design is hypothesized as:

H4: Job analysis and design has positive influence on achieving strategic goal of firm.

\subsection{Career Development Plan}

The concept of career development plan incorporates the process wherein organization identify employee skills, capabilities, weaknesses and strength and train them according to organizational needs and current market demands (Mohammad Ali, 2018). A study conducted by Antoniu (2010) indicates that the role of career planning and development is vital to achieve organizations strategic goal. It is also found that organizations who offer training and development programs to its employees had more enthusiastic and motivated employees (Lam, Dyke, \& Duxbury, 1999; Mohammad Ali, 2018; Mohammad Ali Yamin \& Swaiess, 2019). Author like Baruch (1996) asserted that career plan development create a balance between employee and organizations which help them to overcome future challenges. Career planning activities brings positivity in employee attitude and boost their confidence to survive in competitive industry (Mikacic, 2015; Mohammad Ali, 2018; Mohammad Ali Yamin \& Swaiess, 2019). Similarly, career planning and development impact positively in achieving competitive goal of the firm and help them to achieve competitive advantages (Antoniu, 2010; Mohammed Ali Yousef Yamin, 2020). Therefore and supported by previous literature Jameendar (2014); Mikacic (2015); Mohammad Ali Yamin and Swaiess (2019), we proposed career planning and development as:

H5: Career development plan has positive influence on achieving strategic goal of firm.

\subsection{Employee Creativity}

Employee creativity is seen as the extent wherein employee brings innovation in business operation to achieve business process or services (Zhou \& George, 2003). It is identified as creative concepts with respect to people and business process (Tierney, Farmer, \& Graen, 1999). Human resource literature highlights the importance of employee creativity and its positive impact on achieving strategic goal of the firm (Ha \& Lo, 2018; Hirst et al., 2009; Tierney et al., 1999; Zhou \& George, 2003). According to Zhou and George (2003) asserted that employee creativity introduce novelty in business which in turn enhance business performance. In business world novelty and useful ideas are considered the most important factors that leads to employee creativity (Dewett, 2007; Nguyen \& Hooi, 2020). Organizations provide creative opportunities to employees had more creative employee (Dewett, 2007; Dewettinck \& van Ameijde, 2011; Ha \& Lo, 2018; Hirst et al., 2009). The relationship between employee creativity and achieving strategic goal of firm is found significant (S. Wang \& Noe, 2010). Thus, the current study anticipate that employee creativity helps organization to achieve strategic goal of firm which is also confirmed by previous studies (Dewett, 2007; Ha \& Lo, 2018; Hirst et al., 2009; S. Wang \& Noe, 2010). Thus, employee creativity is outlined as:

H6: Employee creativity has positive influence on achieving strategic goal of firm. 


\subsection{Achieving Strategic Goal of Firm}

The role of succession plan, talent management, staffing plan, job analysis and design, career development plan and employee creativity had showed direct and positive influence in achieving strategic goal of firm (Dobre, 2013). It is established that when employs goals are aligned with company strategic goals, they boost organizational productivity (Elharakany, Moscardini, Khalifa, \& Abd Elghany, 2018; Trybou, Gemmel, Desmidt, \& Annemans, 2017). In addition to that studies found that employee's enthusiasm and strong motivation towards achieving firm goals significantly contributes towards organizational productise (Dewett, 2007; Galli, 2019; Ha \& Lo, 2018; Hirst et al., 2009)(Namatovu \& Semwanga, 2020; Trybou et al., 2017). Earlier studies have found a strong linkage between achieving strategic goal of firm and organizational productivity (Ashraf, 2012; Chakraborty \& Biswas, 2019; Dewett, 2007; Dobre, 2013; Ha \& Lo, 2018; Hirst et al., 2009; Shah, 2011; Trybou et al., 2017); S. Wang and Noe (2010). The alignment between company objectives and employee skills, capacities, abilities and capabilities strengthen organizational productivity and motivate employees to achieve organizational goals (Ashraf, 2012; Chakraborty \& Biswas, 2019; Shah, 2011; Trybou et al., 2017; S. Wang \& Noe, 2010). Therefore and backup by earlier studies Chakraborty and Biswas (2019); Dewett (2007); Dobre (2013); Hirst et al. (2009); Shah (2011); Trybou et al. (2017), achieving strategic goal of firm is hypothesized as:

H7: Achieving strategic goal of firm has positive influence on organizational productivity.

\subsection{Organizational Innovation}

Innovation plays vital role for company success or failure. Organizational innovation significantly impacts in achieving strategic goals of the firm and enhance organizational productivity. The term organizational innovation is defined as an "organization efforts to bring and adopt new and unique methods to carry on daily business activities" (Jimenez-Jimenez et al., 2008; Kiveu, Namusonge, $\&$ Muathe, 2019). Examining the role of organizational innovation is necessary to make employees innovation oriented which in turn boost organizational productivity (Jimenez-Jimenez et al., 2008; Uzkurt et al., 2013). Authors like Uzkurt et al. (2013) asserted that organizations with innovative workforce have been found more goal oriented; thereby investigating the role of organizational innovation is important. A significant and direct relationship is found between organizational innovation and achieving organizational goal (Ha \& Lo, 2018); Hurley and Choudhary (2016); (Irfan \& Marzuki, 2018); Powell (2012); Robson (2013); (Uddin et al., 2013; Uzkurt et al., 2013). Contrary to previous studies, the current study extends the body of knowledge and outlined organizational innovation as moderating variable between achieving strategic goal and organizational productivity (Manu, 1992; Narver, Slater, \& MacLachlan, 2004; Noble, Sinha, \& Kumar, 2002; Siguaw, Simpson, $\&$ Enz, 2006). Following above literature and in line with previous literature Jimenez-Jimenez et al. (2008); Manu (1992); Mittal and Dhar (2015); Narver et al. (2004); Noble et al. (2002); Siguaw et al. (2006); S. Wang and Noe (2010); Wu, Tsai, and Wang (2011), organizational innovation is proposed as (Figure 1):

H8: The positive relationship between achieving strategic goal of firm and organizational productivity will be stronger when organizational innovation is higher. 
Figure 1. The research model

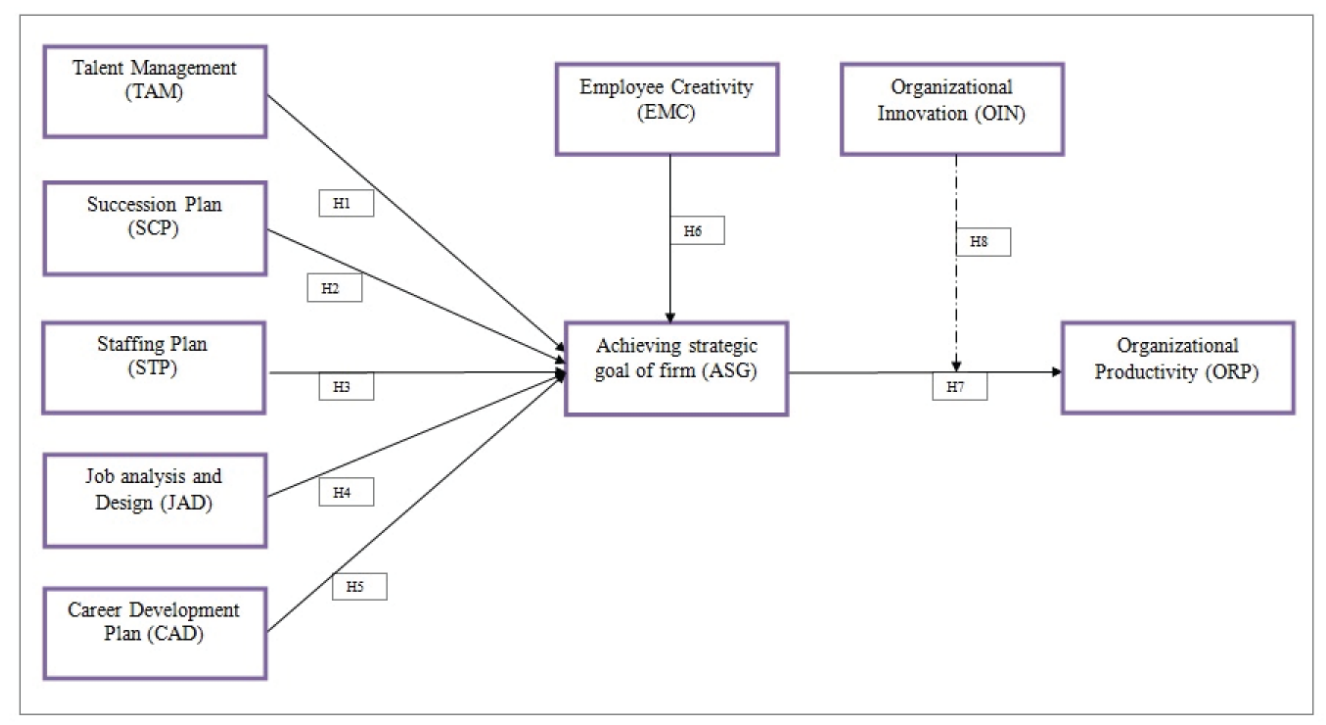

\section{METHODOLOGY}

\subsection{Sampling and Data Collection}

The population of this study is small and medium level of organizations from both public and private sectors of Saudi Arabia. Sample size is calculated with prior-power analysis using G-Power Software as suggested by S Rahi, Ghani, and Ngah (2018). According to S Rahi, Ghani, and Ngah (2018) studies that contains factor analysis must calculate sample size with prior-power analysis. Findings of the prior-power analysis indicated that 245 responses are required at least to predict organizational productivity. However, earlier studies postulated that increase in responses will set reduce the sampling error (Samar Rahi, 2018; S Rahi, Ghani, \& Ngah, 2018). Data is collected using convenience sampling approach in line with earlier studies S. Rahi (2018) and Ghani, Rahi, Yasin, and Alnaser (2017). The use of convenience sampling approach is adequate wherein research aim is to get veracity in data set. Using convenience sampling approach 450 questionnaire were distributed to 118 small and medium levels of organizations. Out of 450, 357 responses were retrieved from organizations. Of these responses 17 responses were discarded due to incomplete filling. Finally, this study incorporates 340 responses for inferential data analysis.

\subsection{Instrument Development}

The aim of this study is to investigate strategic fit of the organizations and organizational productivity. Therefore, the current study develops an amalgamated model which outlines factors such as talent management, succession plan, staffing plan, career development plan, job analysis design, employee creativity and achieving strategic fit of firm to examine organizational productivity. A survey questionnaire was developed with instrument items adapted from previous studies. Instrument items were measured with a seven-point Likert scales ranging from " 1 " strongly disagree to "7" strongly agree in line with previous study (S. Rahi, 2018). Instrument items for the construct talent management adapted from Mohammed (2016). Scale items for the constructs succession plan and staffing plan adapted from Adewale et al. (2011). Job analysis design, career development plan items were adopted from Belias and Sklikas (2013); Tufail et al. (2017) and later adapted in the context of achieving strategic goal of the firm and organizational productivity. Finally, instrument items for 
both endogenous variable strategic goal of the firm and organizational productivity were adopted from Trybou et al. (2017) and then adapted in current study context.

\subsection{Assessing Common Method Variance Issue}

Following positivist paradigm this study collects data using single source. Thus, assessing common method variance bias is essential. In order to confirm that this study is free from common method variance bias help is taken from Harman's single factor analysis. Harman's single factor analysis suggested that variance explained by single factor should not be higher than $50 \%$ indicating that data set is free from biasness (Podsakoff, MacKenzie, Lee, \& Podsakoff, 2003). Findings of the analysis showed that the variance explained by first factor was $15 \%$ and much less than $40 \%$. These findings confirmed that study is free from common method variance bias and valid of structural model assessment.

\section{DATA ANALYSIS AND FINDINGS}

The current study follows quantitative research approach therefore inferential analysis is required to test the relationship among variables. For inferential analysis author has used latest statistical technique namely structural equation modeling (SEM). Structural equation modeling is a statistical technique to test and estimate the causal relationship among variables using data set (Samar Rahi \& Ghani, 2018b; Yamin \& Alyoubi, 2020). Structural equation modeling assessment includes estimation of measurement model and structural model (Anderson \& Gerbing, 1988; Samar Rahi \& Ghani, 2018a). The measurement model assesses convergent validity and discriminant validity of the constructs. On the flip side structural model evaluates the causal relationships between two or more than two variables. For structural equation modeling Smart-PLS Software used (S. Rahi, 2017; Ringle, Wende, \& Becker, 2015).

\subsection{The Measurement Model}

The measurement model estimates convergent and discriminant validity of the constructs. The measurement model comprises assessment of cronbach's $(\alpha)$, composite reliability, indicator loadings and average variance extracted (R. Samar \& Mazuri, 2019a). In order to achieve constructs reliability the values of $(\alpha)$ and CR should be higher than 0.70 as suggested by (Samar Rahi, Ghani, \& Ngah, 2020a). Similarly, factor loading values should be higher than 0.60 indicate adequate reliability of the indicators (R. Samar \& Mazuri, 2019b; Mohammad Ali Yousef Yamin, 2020). Therefore, convergent validity is assessed with average variance extracted and the criterion is that values of AVE should be higher than 0.50 (Fornell \& Larcker, 1981b; Samar Rahi, Abd.Ghani, \& Hafaz Ngah, 2019; M. Yamin, 2020). Findings of the measurement model revealed that all constructs have adequate construct reliability, indicator reliability and convergent validity. Table 1 shows the results of the measurement model.

The values of cronbach's $(\alpha)$, composite reliability, factor loadings and average variance extracted confirmed the convergent validity of the construct. Therefore, the discriminant validity of the constructs is tested with Fornell and Larcker method (S. Samar, Ghani, \& Alnaser, 2017). Discriminant validity is defined as the extent wherein constructs measure distinct concept and differentiate with each other (S Rahi, Ghani, Alnaser, \& Ngah, 2018; Samar Rahi, Ghani, \& Ngah, 2020b). To confirm discriminant validity it is important that the values of AVE must be greater than the correlations of the corresponding variables values (Fornell \& Larcker, 1981a; Samar; Rahi, Khan, \& Alghizzawi, 2020). Findings of the Fornell and Larcker analysis as depicted in Table 2 showed that average variance extracted values (diagonal) are greater than corresponding constructs correlation values. Thus, it is confirmed that construct is discriminant and measure distinct concepts.

Although Fornell and Larcker method shows distinction in concepts, it is important to validate discriminant validity using cross loading method. To achieve discriminant validity the cross loading 


\section{Table 1. The measurement model}

\begin{tabular}{|c|c|c|c|c|}
\hline Items & Loading & $(\boldsymbol{\alpha})$ & CR & AVE \\
\hline \multicolumn{5}{|l|}{ Achieving strategic goal of the firm } \\
\hline $\begin{array}{l}\text { ASG1: Attaining strategic goals increase organizational productivity and guarantee employee's commitment, empowerment and } \\
\text { engagement towards organizations. }\end{array}$ & 0.854 & 0.856 & 0.912 & 0.776 \\
\hline $\begin{array}{l}\text { ASG2: Achieving strategic goals gives opportunity to find new insight and help organizations to manage future challenges and risks } \\
\text { which in turn enhance organizational performance. }\end{array}$ & 0.893 & & & \\
\hline ASG3: Accomplishing strategic goals of the firm on time increase employee competency thereby boost organizational productivity. & 0.896 & & & \\
\hline \multicolumn{5}{|l|}{ Career development plan } \\
\hline $\begin{array}{l}\text { CAD1: My organization provide clear competency profile in which employee measure their performance to achieve organizational } \\
\text { goals. }\end{array}$ & 0.801 & 0.802 & 0.871 & 0.628 \\
\hline CAD2: For career development my organization provides vital services to employee to develop their career path in line with firm goals. & 0.776 & & & \\
\hline CAD3: In my organization employees get self-assessment tools by using that they can map their progress. & 0.811 & & & \\
\hline CAD4: For career development my organization organize workshop that help to achieve employee career goals. & 0.781 & & & \\
\hline \multicolumn{5}{|l|}{ Employee creativity } \\
\hline EMC1: Employee creativity solves problems that create difficulty in firm operations. & 0.976 & 0.968 & 0.979 & 0.941 \\
\hline EMC2: Creative employees use new methods and equipment to approach the problem. & 0.958 & & & \\
\hline EMC3: Employee with creative characteristics are try to bring new ideas and solve the problem. & 0.975 & & & \\
\hline \multicolumn{5}{|l|}{ Job analysis and design } \\
\hline $\begin{array}{l}\text { JAD1: In this organization Job description is properly laid down that helps employers to recruit right person according to organization } \\
\text { objective. }\end{array}$ & 0.806 & 0.920 & 0.944 & 0.809 \\
\hline $\begin{array}{l}\text { JAD2: In this organization Job analysis helps employer to identify, screen and recruit productive and responsible employees to achieve } \\
\text { firms strategic goals. }\end{array}$ & 0.955 & & & \\
\hline $\begin{array}{l}\text { JAD3: In this organization adequate job analysis and design contributes to arrange and shape employee duties and responsibilities } \\
\text { according to firm intent. }\end{array}$ & 0.935 & & & \\
\hline $\begin{array}{l}\text { JAD4: In this organization job analysis and design helps employees to get better insight of organizational operation and they response } \\
\text { proactively. }\end{array}$ & 0.895 & & & \\
\hline \multicolumn{5}{|l|}{ Organization Innovation } \\
\hline OIN1: This organization use innovative methods to attain strategic goal. & 0.816 & 0.798 & 0.882 & 0.713 \\
\hline OIN2: This organization seeks new ways which help them to achieve their goal on time. & 0.834 & & & \\
\hline OIN3: This organization is frequently use innovative ideas that help to achieve firm goal. & 0.882 & & & \\
\hline \multicolumn{5}{|l|}{ Organizational Productivity } \\
\hline ORP1: Comparing with key competitors, my organization performance achieves higher employee satisfaction. & 0.941 & 0.894 & 0.934 & 0.826 \\
\hline ORP2: Comparing with key competitors, my organization performance is growing rapidly. & 0.874 & & & \\
\hline ORP3: Comparing with key competitors, my organization has more innovative and creative employees. & 0.910 & & & \\
\hline \multicolumn{5}{|l|}{ Succession plan } \\
\hline SCP1: Succession plan help organizations to identify high-potential employees that help them to achieve strategic goal of the firm. & 0.912 & 0.890 & 0.923 & 0.750 \\
\hline SCP2: Succession plan help organization to develop leadership qualities among employee that are aligned with firm objectives. & 0.838 & & & \\
\hline $\begin{array}{l}\text { SCP3: In this organization succession plan provide clear road map to employees with mentoring and training services to achieve } \\
\text { strategic goal of the firm. }\end{array}$ & 0.941 & & & \\
\hline $\begin{array}{l}\text { SCP4: This organization provides systematic road map to develop intellectual capital with mentoring and training services that further } \\
\text { help organization to achieve strategic goal. }\end{array}$ & 0.762 & & & \\
\hline \multicolumn{5}{|l|}{ Staffing plan } \\
\hline STP1: In staffing my organization ensures that candidate has right skills to achieve the strategic goal of the firm. & 0.913 & 0.899 & 0.930 & 0.768 \\
\hline $\begin{array}{l}\text { STP2: In staffing my organization analyses the manpower carefully to manager surplus and shortage which help to achieve strategic } \\
\text { goal in future. }\end{array}$ & 0.856 & & & \\
\hline STP3: In staffing my organization focus on employee's skills and competency to achieve firm performance. & 0.866 & & & \\
\hline $\begin{array}{l}\text { STP4: In staffing my organization constantly manage manpower in order to avoid shortage and fulfil personnel needs to achieve } \\
\text { strategic goal. }\end{array}$ & 0.871 & & & \\
\hline \multicolumn{5}{|l|}{ Talent management } \\
\hline TAM1: Talent management requires knowledge, skills and competency of employees to achieve firm goal. & 0.835 & 0.853 & 0.911 & 0.774 \\
\hline TAM2: Talent management provide productive environment to employees and give promotional prospect to achieve organizational goal. & 0.895 & & & \\
\hline TAM3: Talent management encourages and motivate employee with morale upbeat that help them to achieve firm goals & 0.907 & & & \\
\hline
\end{tabular}


Table 2. Fornell and Larcker's analysis

\begin{tabular}{|l|c|c|c|c|c|c|c|c|c|}
\hline \multicolumn{1}{|c|}{ Variables } & ASG & CAD & EMC & JAD & OIN & ORP & SCP & STP & TAM \\
\hline ASG & $\mathbf{0 . 8 8 1}$ & & & & & & & & \\
\hline CAD & 0.436 & $\mathbf{0 . 7 9 2}$ & & & & & & & \\
\hline EMC & 0.771 & 0.351 & $\mathbf{0 . 9 7 0}$ & & & & & & \\
\hline JAD & 0.437 & 0.146 & 0.280 & $\mathbf{0 . 9 0 0}$ & & & & & \\
\hline OIN & -0.019 & 0.012 & -0.019 & -0.104 & $\mathbf{0 . 8 4 4}$ & & & & \\
\hline ORP & 0.406 & 0.244 & 0.281 & 0.213 & 0.133 & $\mathbf{0 . 9 0 9}$ & & & \\
\hline SCP & 0.467 & 0.226 & 0.296 & 0.258 & 0.053 & 0.317 & $\mathbf{0 . 8 6 6}$ & & \\
\hline STP & 0.658 & 0.305 & 0.516 & 0.376 & 0.056 & 0.358 & 0.453 & $\boldsymbol{0 . 8 7 7}$ & \\
\hline TAM & 0.708 & 0.299 & 0.522 & 0.351 & 0.013 & 0.404 & 0.325 & 0.582 & $\mathbf{0 . 8 8 0}$ \\
\hline
\end{tabular}

method suggested that indicator loadings should exceed with other constructs loading. Findings of the measurement model showed that all constructs indicator loading is higher than other constructs loading, confirming that construct is discriminant. Table 3 shows the values of cross loadings.

Assessing discriminant validity is important before structural model estimation (Samar Rahi \& Abd. Ghani, 2019a). Study that is based on primary observation and deal with fresh data collection may affect due to constructs distinction (Gold \& Arvind Malhotra, 2001; Kline, 2011). Earlier studies had criticized on cross loading and Fornell and Larcker methods (Gold \& Arvind Malhotra, 2001; Kline, 2011; Samar Rahi, 2019; Samar Rahi \& Abd. Ghani, 2019b). Consequently, the current study incorporates Heterotrait-Monotrait Ratio (HTMT) analysis to test the discrimiant validity of the construct. Heterotrait-Monotrait Ratio analysis was introduced by Kline (2011) and calculates discriminant validity of the constructs using multitrait and multimethod matrix method. This method advocates that the values of HTMT should not be higher than 0.85 or 0.90 , indicates that construct is discriminant (Samar Rahi \& Abd. Ghani, 2019c). The results of the Heterotrait-Monotrait Ratio analysis revealed that all the values of HTMT were less than 0.85 or 0.90 and confirmed the discriminant validity of the constructs. Table 4 exhibited the results of Heterotrait-Monotrait Ratio analysis using multitrait and multimethod matrix method.

\subsection{Evaluating Structural Model}

Structural model comprises estimation of multicollinearity (VIF), path-coefficients ( $\beta$ ), t-statistics, significance level and coefficient of determination $R^{2}$. The first step of the structural model is to validate lateral multicollinearity using variance inflation factor. Author like Samar Rahi and Abd. Ghani (2018) asserted that lateral multicollinearity issue comes when two constructs measure same variable. Therefore, assessing lateral multicollinearity before structural model is important. To confirm that this study is free from lateral multicollinearity the values of variance inflation factor (VIF) must be less than 3.3, confirming that lateral multicollinearity is not serious issue. Findings of the lateral multicollinearity showed that the VIF values of all exogenous variables are less than 3.3 when comparing with endogenous variables. Table 5 depicts the results of variance inflation factor.

\subsubsection{Hypothesis Testing}

The hypothesized relationship between exogenous and endogenous variables is tested with bootstrapping procedure. Bootstrapping procedure mitigates the data normality issues. Findings of the bootstrap exhibited in Table 6 which includes path-coefficients $(\beta)$, t-statistics and significance level of the constructs. 
Table 3. Cross Loadings

\begin{tabular}{|c|c|c|c|c|c|c|c|c|c|}
\hline & ASG & CAD & EMC & JAD & OIN & ORP & SCP & STP & TAM \\
\hline ASG1 & 0.854 & 0.364 & 0.913 & 0.335 & -0.035 & 0.269 & 0.318 & 0.580 & 0.579 \\
\hline ASG2 & 0.893 & 0.379 & 0.545 & 0.440 & 0.014 & 0.435 & 0.471 & 0.560 & 0.632 \\
\hline ASG3 & 0.896 & 0.410 & 0.562 & 0.381 & -0.029 & 0.374 & 0.451 & 0.597 & 0.663 \\
\hline CAD1 & 0.361 & 0.801 & 0.291 & 0.166 & 0.007 & 0.262 & 0.146 & 0.254 & 0.255 \\
\hline CAD2 & 0.335 & 0.776 & 0.283 & 0.157 & 0.009 & 0.212 & 0.125 & 0.272 & 0.213 \\
\hline CAD3 & 0.337 & 0.811 & 0.293 & 0.061 & -0.015 & 0.195 & 0.197 & 0.222 & 0.262 \\
\hline CAD4 & 0.348 & 0.781 & 0.244 & 0.077 & 0.036 & 0.102 & 0.248 & 0.217 & 0.216 \\
\hline EMC1 & 0.753 & 0.328 & 0.976 & 0.285 & -0.018 & 0.283 & 0.299 & 0.535 & 0.503 \\
\hline EMC2 & 0.750 & 0.348 & 0.958 & 0.266 & -0.028 & 0.270 & 0.294 & 0.478 & 0.529 \\
\hline EMC3 & 0.741 & 0.344 & 0.975 & 0.263 & -0.009 & 0.265 & 0.268 & 0.489 & 0.485 \\
\hline JAD1 & 0.375 & 0.138 & 0.374 & 0.806 & -0.093 & 0.128 & 0.140 & 0.352 & 0.311 \\
\hline JAD2 & 0.436 & 0.151 & 0.228 & 0.955 & -0.091 & 0.228 & 0.287 & 0.347 & 0.326 \\
\hline JAD3 & 0.415 & 0.115 & 0.240 & 0.935 & -0.091 & 0.227 & 0.262 & 0.343 & 0.337 \\
\hline JAD4 & 0.332 & 0.122 & 0.162 & 0.895 & -0.099 & 0.173 & 0.227 & 0.308 & 0.282 \\
\hline OIN1 & -0.030 & -0.005 & -0.022 & -0.092 & 0.816 & 0.116 & 0.031 & 0.051 & -0.013 \\
\hline OIN2 & 0.020 & 0.031 & 0.023 & -0.094 & 0.834 & 0.105 & 0.058 & 0.066 & 0.042 \\
\hline OIN3 & -0.035 & 0.006 & -0.045 & -0.077 & 0.882 & 0.115 & 0.046 & 0.028 & 0.006 \\
\hline ORP1 & 0.351 & 0.242 & 0.254 & 0.154 & 0.112 & 0.941 & 0.244 & 0.322 & 0.367 \\
\hline ORP2 & 0.419 & 0.219 & 0.258 & 0.285 & 0.108 & 0.874 & 0.376 & 0.368 & 0.411 \\
\hline ORP3 & 0.330 & 0.201 & 0.252 & 0.129 & 0.145 & 0.910 & 0.232 & 0.277 & 0.315 \\
\hline SCP1 & 0.396 & 0.209 & 0.245 & 0.225 & 0.063 & 0.280 & 0.912 & 0.382 & 0.254 \\
\hline SCP2 & 0.493 & 0.242 & 0.354 & 0.225 & 0.045 & 0.278 & 0.838 & 0.473 & 0.379 \\
\hline SCP3 & 0.412 & 0.171 & 0.229 & 0.270 & 0.049 & 0.294 & 0.941 & 0.389 & 0.275 \\
\hline SCP4 & 0.248 & 0.135 & 0.136 & 0.149 & 0.019 & 0.239 & 0.762 & 0.272 & 0.152 \\
\hline STP1 & 0.584 & 0.261 & 0.607 & 0.309 & 0.029 & 0.275 & 0.332 & 0.913 & 0.511 \\
\hline STP2 & 0.593 & 0.289 & 0.320 & 0.390 & 0.069 & 0.383 & 0.495 & 0.856 & 0.531 \\
\hline STP3 & 0.593 & 0.299 & 0.351 & 0.312 & 0.053 & 0.364 & 0.475 & 0.866 & 0.532 \\
\hline STP4 & 0.531 & 0.212 & 0.545 & 0.304 & 0.046 & 0.222 & 0.272 & 0.871 & 0.461 \\
\hline TAM1 & 0.593 & 0.253 & 0.651 & 0.270 & 0.006 & 0.256 & 0.198 & 0.523 & 0.835 \\
\hline TAM2 & 0.628 & 0.239 & 0.350 & 0.353 & 0.036 & 0.431 & 0.336 & 0.483 & 0.895 \\
\hline TAM3 & 0.647 & 0.296 & 0.389 & 0.301 & -0.007 & 0.373 & 0.317 & 0.531 & 0.907 \\
\hline
\end{tabular}

Structural model results indicate that talent management had significant influence on achieving strategic goal of firm and supported by H1: $(\beta=0.287$, t-value 5.479, significance $\mathrm{p}<0.001)$. Succession plan had significant influence on achieving strategic goal of firm and supported by $\mathrm{H} 2:(\beta=0.131$, $\mathrm{t}$-value 3.854, significance $\mathrm{p}<0.001$ ). The relationship between staffing plan and achieving strategic goal of firm was confirmed and supported by H3: $(\beta=0.123$, t-value 2.631 , significance $p<0.001)$. Next to this, Job analysis and design had showed significant influence on achieving strategic goal of 
Table 4. Heterotrait-Monotrait Ratio (HTMT) analysis

\begin{tabular}{|l|l|l|l|l|l|l|l|l|l|}
\hline & ASG & CAD & EMC & JAD & OIN & ORP & SCP & STP & TAM \\
\hline ASG & & & & & & & & & \\
\hline CAD & 0.526 & & & & & & & & \\
\hline EMC & 0.840 & 0.398 & & & & & & & \\
\hline JAD & 0.490 & 0.169 & 0.296 & & & & & & \\
\hline OIN & 0.045 & 0.050 & 0.041 & 0.122 & & & & & \\
\hline ORP & 0.463 & 0.286 & 0.302 & 0.227 & 0.158 & & & & \\
\hline SCP & 0.514 & 0.258 & 0.300 & 0.274 & 0.061 & 0.347 & & & \\
\hline STP & 0.748 & 0.356 & 0.557 & 0.412 & 0.067 & 0.392 & 0.484 & & \\
\hline TAM & 0.829 & 0.361 & 0.580 & 0.394 & 0.037 & 0.457 & 0.349 & 0.664 & \\
\hline
\end{tabular}

Note: Heterotrait-Monotrait Ratio (HTMT) discriminate at (HTMT <0.9/ HTMT <0.85)

\section{Table 5. The variance inflation factor}

\begin{tabular}{|l|l|l|}
\hline \multicolumn{1}{|c|}{ Constructs } & Achieving strategic goal of firm & Organizational Productivity \\
\hline Achieving strategic goal of firm & & 1.000 \\
\hline Career development plan & 1.185 & \\
\hline Employee Creativity & 1.586 & \\
\hline Job analysis and design & 1.215 & \\
\hline Organizational Innovation & & 1.000 \\
\hline Succession plan & 1.291 & \\
\hline Staffing plan & 1.914 & \\
\hline Talent management & 1.736 & \\
\hline
\end{tabular}

firm and confirmed by H4: $(\beta=0.114$, $\mathrm{t}$-value 3.615, significance $\mathrm{p}<0.001)$. Career development plan had showed positive and significant influence in achieving strategic goal of firm and accepted H5: $(\beta=0.109$, t-value 4.431, significance $p<0.001)$. Extending to this employee creativity had showed positive influence in achieving strategic goal of firm and accepted H6: $(\beta=0.449$, t-value

\section{Table 6. Results of hypothesis}

\begin{tabular}{|l|l|l|l|l|l|c|}
\hline \multicolumn{1}{|c|}{ Hypotheses } & \multicolumn{1}{c|}{ Relationship } & \multicolumn{1}{c|}{ Beta $(\boldsymbol{\beta})$} & \multicolumn{1}{c|}{ SE } & \multicolumn{1}{c|}{ T-Statistics } & Significance & Result \\
\hline H1 & TAM -> ASG & 0.287 & 0.052 & 5.479 & 0.000 & Accepted \\
\hline H2 & SCP -> ASG & 0.131 & 0.034 & 3.854 & 0.000 & Accepted \\
\hline H3 & STP - > ASG & 0.123 & 0.047 & 2.631 & 0.009 & Accepted \\
\hline H4 & JAD - > ASG & 0.114 & 0.032 & 3.615 & 0.000 & Accepted \\
\hline H5 & CAD - > ASG & 0.109 & 0.025 & 4.431 & 0.000 & Accepted \\
\hline H6 & EMC - > ASG & 0.449 & 0.062 & 7.256 & 0.000 & Accepted \\
\hline H7 & ASG -> ORP & 0.409 & 0.062 & 6.615 & 0.000 & Accepted \\
\hline
\end{tabular}


7.256, significance $\mathrm{p}<0.001)$. Finally, achieving strategic goal of firm had significant impact on organizational productivity and accepted H7: $(\beta=0.409$, t-value 6.615 , significance $\mathrm{p}<0.001)$. Structural model analysis indicates substantial variance in achieving strategic goal of firm and organizational productivity (Chin, 1998). Achieving strategic goal of firm was jointly predicted by talent management, succession plan, staffing plan, Job analysis and design, career development plan and employee creativity and explained $R^{2} 78.9 \%$ variance in achieving strategic goal of firm. Therefore, organizational productivity was predicted by achieving strategic goal of firm and organizational innovation and showed $R^{2} 20.7 \%$ of variance when in organizational productivity. These findings confirmed the validity of the model to determine organizational productivity.

\subsubsection{Effect Sizes $\left(f^{2}\right)$, Predictive Relevance $Q^{2}$}

It is argued that coefficient of determination $R^{2}$ shows variance explained by all exogenous variables on endogenous variables. Contrary to this, $f^{2}$ analysis reveal individual independent variables effect on dependent variables (Samar Rahi, 2017). Authors like S Rahi, Ghani, and Ngah (2018) asserted that effect size analysis shows actual size of the variable when assessing causal relationship between independent variable and dependent variable. Thus, the effect size analysis is incorporated in this study to see which factor holds maximum weight to achieve strategic goal of firm and organizational productivity. Findings of the PLS-Algorithm highlight the importance of factors with effect size. Findings of the effect size $f^{2}$ analysis indicate that employee creativity had the highest effect size on achieving strategic goal of firm. Therefore, talent management had second highest effect size. Concerning with other exogenous variables such as succession plan, staffing plan, job analysis and design.

Organizational productivity is predicted by achieving strategic goal of firm and organizational innovation. Results showed that achieving strategic goal of firm had medium size effect therefore organizational innovation had small effect size. These findings confirmed that employee creativity and talent management are the most influential factor to achieve strategic goal of firm and organizational productivity. Aside of coefficient of determination $R^{2}$ and effect size analysis, the research model was also confirmed with predictive relevance using blindfolding procedure $Q^{2}$. To achieve adequate predictive relevance the values of $Q^{2}$ must be higher than 0 reflecting appropriate predictive relevance of the model (S. Rahi, 2018). Findings of the blindfolding procedure $Q^{2}$ are greater than 0 indicating that the current model has adequate predictive relevance and contribute to theory and practice. Table 7 shows the predictive relevance and effect size of the constructs.

\subsection{Moderating Analysis}

The structural equation modeling (SEM) reveals that underpinning factors such as talent management, succession plan, staffing plan, employee creativity and career development plan significantly influence on achieving strategic goal of firm. Aside of direct relationship the current study adds moderating role of organizational innovation between achieving strategic goal of firm and organizational productivity. Organizational innovation is outlined as "the positive relationship between achieving strategic goal of firm and organizational productivity will be stronger when organizational innovation is higher". To test the moderating relationship researcher used product indicator approach which is consistent with previous studies (Henseler \& Fassott, 2010; Samar Rahi, 2015, 2016; Samar Rahi \& Ghani, 2016). Findings of the structural model showed that interaction effect between achieving strategic goal of firm and organizational innovation is significant and supported by H8: $(\beta=0.153, \mathrm{t}-2.063 \mathrm{p}<0.05)$. The results of the moderating analysis depicted in Figure 2.

The interaction effect between achieving strategic goal of firm and organizational innovation is found significant. Therefore, the strength of the moderating relationship is needed to be examined. The present study uses simple slope analysis to see the strength of the relationship. Results of simple 
Table 7. Predictive relevance $Q^{2}$ and Effect size analysis $\left(f^{2}\right)$

\begin{tabular}{|c|c|c|c|c|}
\hline \multicolumn{5}{|c|}{ Achieving strategic goal of firm } \\
\hline Construct & $\boldsymbol{R}^{2}$ & $Q^{2}$ & $\left(f^{2}\right)$ & Decision \\
\hline Achieving strategic goal of firm & 0.789 & 0.578 & & \\
\hline Career development plan & & & 0.047 & Small \\
\hline Employee creativity & & & 0.602 & Substantial \\
\hline Job analysis and design & & & 0.051 & Small \\
\hline Succession plan & & & 0.063 & Small \\
\hline Staffing plan & & & 0.038 & Small \\
\hline Talent management & & & 0.226 & Medium \\
\hline \multicolumn{5}{|l|}{ Organizational Productivity } \\
\hline Construct & $\boldsymbol{R}^{2}$ & $Q^{2}$ & $\left(\boldsymbol{f}^{2}\right)$ & Decision \\
\hline Organizational Productivity & 0.207 & 0.157 & & \\
\hline Achieving strategic goal of firm & & & 0.211 & Medium \\
\hline Organizational Innovation & & & 0.025 & Small \\
\hline
\end{tabular}

slope analysis showed that organizational innovation has steeper and positive gradient at+1SD when it is compared with negative gradient of organizational innovation at-1SD exhibiting less steep and positive. These findings suggested that the positive relationship between achieving strategic goal of firm and organizational productivity will be stronger when organizational innovation is higher. Therefore, human resource manager should focus on organizational innovation to enhance organizational productise. Simple slope analysis gradient is depicted in Figure 3.

\section{DISCUSSION}

The importance of human resource department holds key position in an organization. Selection of the employee is considered crucial process and success of the organization is dependent on employee's productivity which leads employees towards organizational productivity. The newly developed research model showed that achieving strategic goal of the firm was predicted by staffing plan, succession plan, job analysis and design, talent management, career development plan, employee creativity and organizational innovation and explained $R^{2} 78.9 \%$ variance in achieving strategic goal of firm. On the other side organizational productivity was predicted by organizational innovation and achieving strategic goal of firm and explained $R^{2} 20.7 \%$ variance in organizational productivity. Hence, these results confirmed the validity and generalizability of the model to predict strategic goal and organizational productivity of the firm. The research model confirmed that talent management has significant influence on achieving strategic goal of firm and in line with previous studies (Aslam et al., 2013; Ekwoaba et al., 2015; Saddam \& Mansor, 2015; Schroeder, 2012). The second construct is succession plan which showed significant influence in achieving strategic goal of firm and supported by earlier studies (Adewale et al., 2011; Das, 2013; Komora et al., 2015; Seniwoliba, 2015). 


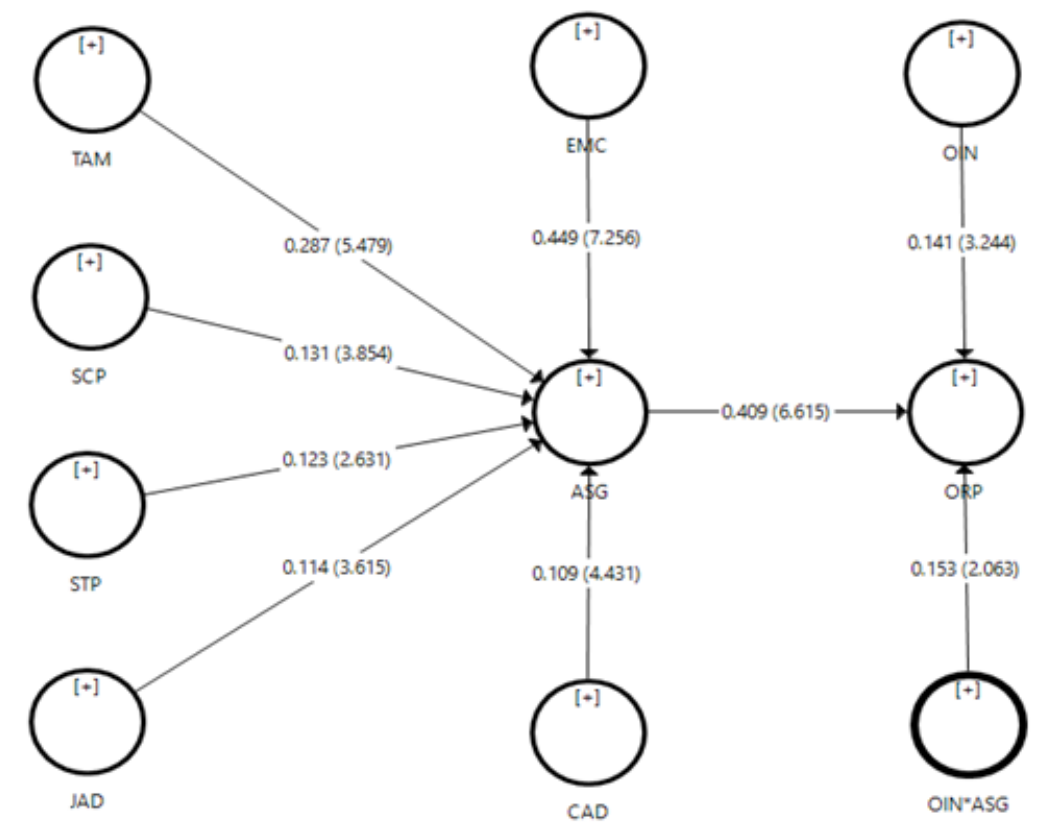

Similarly, the relationship between staffing plan and achieving strategic goal of firm is confirmed and similar with Chakraborty and Biswas (2019); Maih (2015); Saddam and Mansor (2015). The Job analysis and design has showed significant influence in achieving strategic goal of the firm and consistent with (Belias \& Sklikas, 2013; Tufail et al., 2017). Career development plan has showed positive and significant influence in achieving strategic goal of firm and supported with previous studies (Lam et al., 1999; Mohammad Ali Yamin \& Swaiess, 2019). The relationship between employee creativity and achieving strategic goal of firm was confirmed and consistent with (Ha \& Lo, 2018; Hirst et al., 2009; Tierney et al., 1999; Zhou \& George, 2003). The first endogenous variables namely achieving strategic goal of firm had showed significant impact on organizational productivity and consistent with earlier studies (Trybou et al., 2017). Finally, this study adds organizational innovation as moderating variable between achieving strategic goal of firm and organizational productivity. Results confirmed that the positive relationship between achieving strategic goal of firm and organizational productivity will be stronger when organizational innovation is higher. These findings contribute

Figure 3. Simple slope analysis of organizational innovation

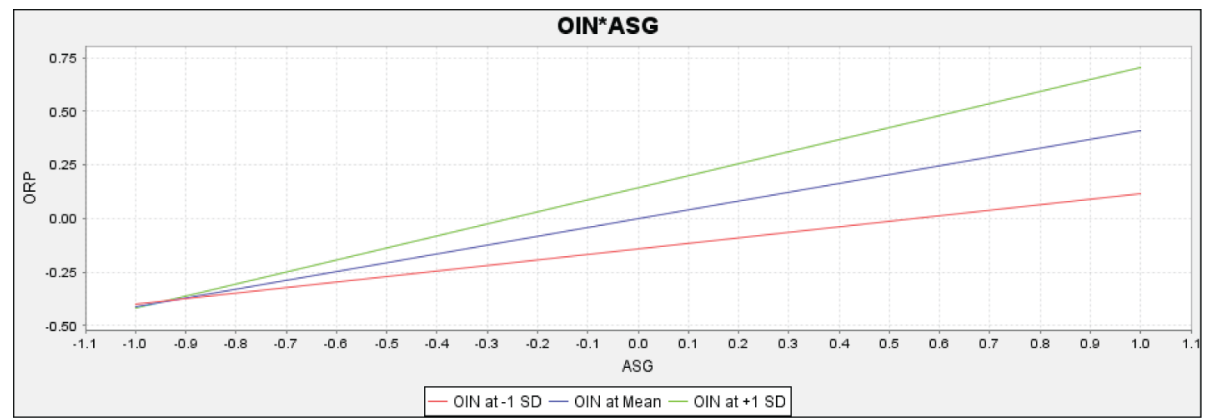


to theory and practice and impute future research directions to academic researchers and human resource managers to examine employee intention towards achieving strategic goal of the firm and organizational productivity.

\subsection{Theoretical and Practical Implications}

The present study has several contributions to theory and practice. First, it synthesizes the human resource literature and concluded that staffing plan, talent management, succession plan, job analysis and design are the essential factors when determining the role of human resource planning. Second, it adds other factors such as employee creativity and organizational innovation in human resource planning (HRP) model. Extension of human resource planning with employee creativity and organizational innovation enrich the literature and imputes future directions to academic researchers. For managerial implications, this study highlights that employee creativity, talent management and achieving strategic goal of the firm are the most important constructs in predicting organizational productivity. Therefore, human resource managers and policy makers should focus on employee creativity and talent management in order to boost employee intention towards achieving strategic goal of firm and organizational productivity. In addition to that managers also need to focus on organization innovation as it moderates the relationship between achieving strategic goal of the firm and organizational productivity.

\section{CONCLUSION}

The role of employee is integral to achieve strategic goal and organizational productivity of the firm. In today's competitive business world employees are willing to participate in strategic planning of the organization. Therefore, it is possible only when human resource department plays vital role in hiring right employee for right job. Thus, the aim of this study is to investigate factors that impact on strategic goals of the firm and organizational productivity. The research model indicates that achieving strategic goal of the firm is predicted by staffing plan, succession plan, job analysis and design, talent management, career development plan, employee creativity and organizational innovation and explained $R^{2} 78.9 \%$ variance in achieving strategic goal of firm. These findings confirmed that the research model has substantial power to predict strategic goal of the organizations and organizational productivity. Findings of the effect size $f^{2}$ analysis indicate that employee creativity had the highest effect size in achieving strategic goal of firm. Therefore, talent management had second highest effect size. The predictive relevance of the model was checked using blindfolding procedure $Q^{2}$. Results showed that the values of blindfolding procedure $Q^{2}$ are higher than 0 confirming that the current model has adequate predictive relevance and valid. For managerial implications, this study suggest that employee creativity, organizational innovation and talent management had intermediate level of importance to predict organizational productivity. These findings impute that employee creativity, organizational innovation, talent management and achieving strategic goal of firm are the most important constructs in predicting organizational productivity. Therefore, human resource managers and policy makers should focus on employee creativity, organizational innovation and talent management in order to boost employee intention towards achieving strategic goal of firm and organizational productivity.

\subsection{Limitations and Future Research Directions}

The focus of this study is to examine organizational productivity while studying factors such as human resource planning (HRP), employee creativity and organizational innovation. Therefore, it is not confirmed that factor investigated in the research model explained maximum variance. Thus, future research may conduct adding some motivational factors such as autonomy and efficacy. The current study is conducted in Saudi small medium organization context and includes data from one 
country. Replicating current research model in South Asian countries could reveal interesting findings. Achieving strategic goal of the firm is studied as an endogenous variable in this study. Therefore, considering strategic goal of the firm as mediator variable between human resource planning and organizational productivity may alter the results. Finally, this study is cross-sectional therefore future researchers may administrate newly developed research model in longitudinal context.

\section{ACKNOWLEDGEMENT}

This work was funded by the University of Jeddah, Jeddah, Saudi Arabia, under grant No. (UJ-20090-DR). the authors, therefore, acknowledge with thank the university of Jeddah technical and financial support. 


\section{REFERENCES}

Abazeed, R. A. M. (2018). The impact of talent management on organizational commitment of the employees of telecommunication companies in Jordan: The mediating role of employee work engagement. International Journal of Academic Research in Accounting, Finance and Management Sciences, 8(4), 153-162.

Adewale, O. O., Abolaji, A. J., \& Kolade, O. J. (2011). Succession planning and organizational survival: Empirical study on Nigerian private tertiary institutions. Serbian Journal of Management, 6(2), 231-246. doi:10.5937/ sjm1102231A

Anderson, J. C., \& Gerbing, D. W. (1988). Structural equation modeling in practice: A review and recommended two-step approach. Psychological Bulletin, 103(3), 411-423. doi:10.1037/0033-2909.103.3.411

Anilkumar, E., \& Sridharan, R. (2019). Sustainable Supply Chain Management: A Literature Review and Implications for Future Research. International Journal of System Dynamics Applications, 8(3), 15-52. doi:10.4018/IJSDA.2019070102

Antoniu, E. (2010). Career planning process and its role in human resource development. Annals of the University of Petrosani. Economics, 10(2), 13-22.

Ashraf, G., \& Bte Abd Kadir, S. (2012). A Review on the Models of Organizational Effectiveness: A Look at Cameron's Model in Higher Education. International Education Studies, 5(2), 80-87. doi:10.5539/ies.v5n2p80

Aslam, H. D., Aslam, M., Ali, N., \& Habib, B. (2013). Importance of Human Resource Management in 21 st Century: A Theoretical Perspective. Organization, 3(3).

Baruch, Y. (1996). Organizational career planning and management techniques and activities in use in high-tech organizations. Career Development International, 1(1), 40-49. doi:10.1108/13620439610111426

Belias, D., \& Sklikas, D. (2013). Aspects of job design. International Journal of Human Resource Management and Research, 3(4), 85-94.

Chakraborty, D., \& Biswas, W. (2019). Evaluating the impact of human resource planning programs in addressing the strategic goal of the firm. Journal of Advances in Management Research.

Chin, W. W. (1998). Commentary: Issues and opinion on structural equation modeling. JSTOR.

Das, D. (2013). The Romance of Human Resource Management. Himalaya Publishing House.

Deci, E. L., \& Ryan, R. M. (1985). The general causality orientations scale: Self-determination in personality. Journal of Research in Personality, 19(2), 109-134. doi:10.1016/0092-6566(85)90023-6

Deci, E. L., \& Ryan, R. M. (2000). The" what" and" why" of goal pursuits: Human needs and the selfdetermination of behavior. Psychological Inquiry, 11(4), 227-268. doi:10.1207/S15327965PLI1104_01

Dewett, T. (2007). Linking intrinsic motivation, risk taking, and employee creativity in an R\&D environment. $R \&$ D Management, 37(3), 197-208. doi:10.1111/j.1467-9310.2007.00469.x

Dewettinck, K., \& van Ameijde, M. (2011). Linking leadership empowerment behaviour to employee attitudes and behavioural intentions. Personnel Review, 40(3), 284-305. doi:10.1108/00483481111118621

Dobre, O.-I. (2013). Employee motivation and organizational performance. Review of Applied Socio-Economic Research, 5(1).

Ehsan, H. (2018). Impact of performance appraisal, work design and compensation on employee performance: A study of telecom sector. Journal of Global Economics, 6(1), 301-320. doi:10.4172/2375-4389.1000301

Ekwoaba, J. O., Ikeije, U. U., \& Ufoma, N. (2015). The Impact of Recruitment and Selection Criteria on Organizational Performance. Academic Press.

Elharakany, R. A., Moscardini, A., Khalifa, N. M., \& Abd Elghany, M. M. (2018). Modelling the Effect on Quality of Information and Communications Technology (ICT) facilities in Higher Education: Case Study-Egyptian Universities. International Journal of System Dynamics Applications, 7(3), 1-30. doi:10.4018/IJSDA.2018070101 
Fornell, C., \& Larcker, D. F. (1981). Structural Equation Models With Unobservable Variables and Measurement Error: Algebra and Statistics. JMR, Journal of Marketing Research, 18(3), 382-388. doi:10.1177/002224378101800313

Galli, B. J. (2018). Application of system engineering to project management: How to view their relationship. International Journal of System Dynamics Applications, 7(4), 76-97. doi:10.4018/IJSDA.2018100105

Galli, B. J. (2019). Thoughts of Using Economic Decision-Making to Systems Engineering and Systems Thinking: An Exploratory Study. International Journal of System Dynamics Applications, 8(3), 1-14. doi:10.4018/ IJSDA.2019070101

Ghani, M. A., Rahi, S., Yasin, N. M., \& Alnaser, F. M. (2017). Adoption of Internet Banking: Extending the Role of Technology Acceptance Model (TAM) with E-Customer Service and Customer Satisfaction. World Applied Sciences Journal, 35(9), 1918-1929.

Gold, A. H., \& Arvind Malhotra, A. H. S. (2001). Knowledge management: An organizational capabilities perspective. Journal of Management Information Systems, 18(1), 185-214. doi:10.1080/07421222.2001.11045669

Ha, S. T., \& Lo, M. C. (2018). An empirical examination of knowledge management and organisational performance among Malaysian manufacturing SMEs. International Journal of Business Innovation and Research, 17(1), 23-37. doi:10.1504/IJBIR.2018.094196

Henseler, J., \& Fassott, G. (2010). Testing moderating effects in PLS path models: An illustration of available procedures. In Handbook of partial least squares. Springer.

Hirst, G., Van Dick, R., \& Van Knippenberg, D. (2009). A social identity perspective on leadership and employee creativity. Journal of Organizational Behavior: The International Journal of Industrial, Occupational and Organizational Psychology and Behavior, 30(7), 963-982. doi:10.1002/job.600

Hurley, D., \& Choudhary, A. (2016). Factors influencing attainment of CEO position for women. Gender in Management, 31(4), 250-265. doi:10.1108/GM-01-2016-0004

Irfan, S., \& Marzuki, N. A. (2018). Hierarchy culture as a moderator on the relationship between work motivation and work commitment. Indian Journal of Positive Psychology, 9(1), 89-96. doi:10.15614/ijpp.v9i01.11749

Jameendar, R. (2014). Career Planning Is Essential Process and Element For Employees and Organizational Development. Academic Press.

Jimenez-Jimenez, D., Sanz Valle, R., \& Hernandez-Espallardo, M. (2008). Fostering innovation: The role of market orientation and organizational learning. European Journal of Innovation Management, 11(3), $389-412$. doi:10.1108/14601060810889026

Kiumarsi, S., Isa, S. M., Jayaraman, K., Amran, A., \& Hashemi, S. (2020). The effect of service innovation on service loyalty in post offices. International Journal of Business Innovation and Research, 21(1), $108-127$. doi:10.1504/IJBIR.2020.104035

Kiveu, M. N., Namusonge, M., \& Muathe, S. (2019). Effect of innovation on firm competitiveness: The case of manufacturing SMEs in Nairobi County, Kenya. International Journal of Business Innovation and Research, 18(3), 307-327. doi:10.1504/IJBIR.2019.098251

Kline, R. (2011). Principles and Practice of Structural Equation Modeling (3rd ed.). Guilford Press.

Komaki, J. (2003). Reinforcement theory at work: Enhancing and explaining what employees do. Motivation and Work Behavior, 95-113.

Komora, A., Guyo, P. W., \& Odhiambo, R. (2015). Influence of business goals on effective implementation of succession management in state enterprises in Kenya. Academic Press.

Lam, N., Dyke, L., \& Duxbury, L. (1999). Career development in best-practice organizations: Critical success factors. Optimum (Paris), 29(4), 22-30.

Lyria, R. K. (2015). Effect of talent management on organizational performance in companies listed in Nairobi securities exchange in Kenya. Academic Press. 
Maih, C. (2015). Assessing the role of staffing on the performance of micro finance organizations. Case Study. Awing Central Credit Union Ltd.

Maimone, F., \& Sinclair, M. (2014). Dancing in the dark: Creativity, knowledge creation and (emergent) organizational change. Journal of Organizational Change Management, 27(2), 344-361. doi:10.1108/JOCM12-2012-0197

Mangusho, Y. S., Murei, R. K., \& Nelima, E. (2015). Evaluation of talent management on employees performance in beverage industry: A case of delmonte Kenya Limited. International Journal of Humanities and Social Science, 5(8), 191-199.

Manu, F. A. (1992). Innovation orientation, environment and performance: A comparison of US and European markets. Journal of International Business Studies, 23(2), 333-359. doi:10.1057/palgrave.jibs.8490271

Mardani, A., Nikoosokhan, S., Moradi, M., \& Doustar, M. (2018). The Relationship Between Knowledge Management and Innovation Performance. The Journal of High Technology Management Research, 29(1), 12-26. doi:10.1016/j.hitech.2018.04.002

Martín Cruz, N., Martín Pérez, V., \& Trevilla Cantero, C. (2009). The influence of employee motivation on knowledge transfer. Journal of Knowledge Management, 13(6), 478-490. doi:10.1108/13673270910997132

Mikacic, M. T. (2015). The effects of career planning education. RUO. Revija za Univerzalno Odlicnost, 4(3), 92.

Mittal, S., \& Dhar, R. L. (2015). Transformational leadership and employee creativity: Mediating role of creative self-efficacy and moderating role of knowledge sharing. Management Decision, 53(5), 894-910. doi:10.1108/ MD-07-2014-0464

Mohammad Ali, Y. (2018). The mediating role of ethical organizational climate between HRM practices and HR outcomes in Public Sector of Saudi Arabia. International Journal of Business Excellence. Advance online publication. doi:10.1504/IJBEX.2019.10016985

Mohammed, A. (2016). The impact of talent management on employee engagement, retention and value addition in achieving organizational performance. International Journal of Engineering and Management, 1(12), 142-152.

Mwanzi, J., Wamitu, S. N., \& Kiama, M. (2017). Influence of talent management on organizational growth. Academic Press.

Naeiji, M. J., \& Siadat, S. H. (2018). Developing a measurement for strategic entrepreneurship by linking its dimensions to competitiveness in knowledge-based firms. International Journal of Business Innovation and Research, 18(1), 1-18. doi:10.1504/IJBIR.2019.096895

Namatovu, H. K., \& Semwanga, A. R. (2020). A Systems Dynamics Approach to Understanding the Determinants of Antenatal Care Utilization in Low-and Middle-Income Countries: A Systematic Review. International Journal of System Dynamics Applications, 9(4), 111-128. doi:10.4018/IJSDA.2020100106

Narver, J. C., Slater, S. F., \& MacLachlan, D. L. (2004). Responsive and proactive market orientation and new-product success. Journal of Product Innovation Management, 21(5), 334-347. doi:10.1111/j.07376782.2004.00086.x

Nguyen, N. T., \& Hooi, L. W. (2020). Relationship between leadership styles, employee creativity and organisational innovation: A proposed framework. International Journal of Business Innovation and Research, 22(1), 23-46. doi:10.1504/IJBIR.2020.107143

Noble, C. H., Sinha, R. K., \& Kumar, A. (2002). Market orientation and alternative strategic orientations: A longitudinal assessment of performance implications. Journal of Marketing, 66(4), 25-39. doi:10.1509/ jmkg.66.4.25.18513

Okoye, E. I. (2007). Job Analysis in Manpower Planning of Business Organizations; An Assessment of the Significance. The International Journal Series on Tropical Issues, 8(1).

Omidi, F., \& Shafiee, M. M. (2018). The impact of corporate social responsibility on social performance, financial performance and customer reactions in the food industry. International Journal of Business Innovation and Research, 17(2), 249-265. doi:10.1504/JJBIR.2018.094767 
Pasha, S. M., \& Ahmed, B. (2017). A study on talent management strategies in IT industry. International Research Journal of Engineering and Technology, 4(4), 1384-1387.

Podsakoff, P. M., MacKenzie, S. B., Lee, J.-Y., \& Podsakoff, N. P. (2003). Common method biases in behavioral research: A critical review of the literature and recommended remedies. The Journal of Applied Psychology, 88(5), 879-903. doi:10.1037/0021-9010.88.5.879 PMID:14516251

Powell, G. N. (2012). Six ways of seeing the elephant: The intersection of sex, gender, and leadership. Gender in Management, 27(2), 119-141. doi:10.1108/17542411211214167

Rahi, S. (2015). Moderating role of brand image with relation to internet banking and customer loyalty: A case of branchless banking. Journal of Internet Banking and Commerce, 20(3). Advance online publication. doi:10.4172/1204-5357.1000131

Rahi, S. (2016). Impact of Customer Perceived Value and Customers Perception of Public Relation on Customer Loyalty with Moderating Role of Brand Image. Journal of Internet Banking and Commerce, 21(2).

Rahi, S. (2017). Research design and methods: A systematic review of research paradigms, sampling issues and instruments development. International Journal of Economics \& Management Sciences, 6(2), 1-5. doi:10.4172/2162-6359.1000403

Rahi, S. (2017). Structural Equation Modeling Using SmartPLS. CreateSpace Independent Publishing Platform.

Rahi, S. (2018). Examining the Effects of Travel Constraints, Tourist Satisfaction and Website Image on Tourist Loyalty in Developing Countries Context. Economic and Social Development: Book of Proceedings, 478-487.

Rahi, S. (2018). Research Design and Methods. CreateSpace Independent Publishing Platform.

Rahi, S., \& Abd. Ghani, M. (2019b). Integration of expectation confirmation theory and self-determination theory in internet banking continuance intention. Journal of Science and Technology Policy Management. 10.1108/JSTPM-06-2018-0057

Rahi, S., \& Abd. Ghani, M. (2018). The role of UTAUT, DOI, perceived technology security and game elements in internet banking adoption. World Journal of Science, Technology and Sustainable Development, 15(4), 338-356. doi:10.1108/WJSTSD-05-2018-0040

Rahi, S., \& Abd. Ghani, M. (2019a). Does gamified elements influence on user's intention to adopt and intention to recommend internet banking? International Journal of Information and Learning Technology, 36(1), 2-20. doi:10.1108/IJILT-05-2018-0045

Rahi, S., \& Abd. Ghani, M. (2019c). Investigating the role of UTAUT and e-service quality in internet banking adoption setting. The TQM Journal, 31(3), 491-506. doi:10.1108/TQM-02-2018-0018

Rahi, S., Abd.Ghani, M., \& Hafaz Ngah, A. (2019). Integration of unified theory of acceptance and use of technology in internet banking adoption setting: Evidence from Pakistan. Technology in Society, 58, 101120. doi:10.1016/j.techsoc.2019.03.003

Rahi, S., Ghani, M., Alnaser, F., \& Ngah, A. (2018). Investigating the role of unified theory of acceptance and use of technology (UTAUT) in internet banking adoption context. Management Science Letters, 8(3), 173-186. doi:10.5267/j.msl.2018.1.001

Rahi, S., Ghani, M., \& Ngah, A. (2018). A structural equation model for evaluating user's intention to adopt internet banking and intention to recommend technology. Accounting, 4(4), 139-152. doi:10.5267/j.ac.2018.3.002

Rahi, S., \& Ghani, M. A. (2016). Customer's Perception of Public Relation in E-Commerce and its Impact on E-Loyalty with Brand Image and Switching Cost. Journal of Internet Banking and Commerce, 21(3).

Rahi, S., \& Ghani, M. A. (2018a). Investigating the Role of E-Service Quality and Brand Image in Internet Banking Acceptance Context with Structural Equation Modeling (SEM-PLS). Paper presented at 30th International Scientific Conference on Economic and Social Development.

Rahi, S., \& Ghani, M. A. (2018b). A Structural Equation Modeling (SEM-AMOS) for Investigating Brand Loyalty and Customer's Intention towards Adoption of Internet Banking Paper presented at the 29th International Scientific Conference on Economic and Social Development. 
Rahi, S., Ghani, M. A., \& Ngah, A. H. (2020). Factors propelling the adoption of internet banking: The role of e-customer service, website design, brand image and customer satisfaction. International Journal of Business Information Systems, 33(4), 549-569. doi:10.1504/IJBIS.2020.105870

Rahi, S., Khan, M. M., \& Alghizzawi, M. (2020). Extension of technology continuance theory (TCT) with Task technology fit (TTF) in the context of internet banking user continuance intention. International Journal of Quality \& Reliability Management, O(0), 986-1004. Advance online publication. doi:10.1108/IJQRM-03-2020-0074

Rahi, S., Othman Mansour, M. M., Alghizzawi, M., \& Alnaser, F. M. (2019). Integration of UTAUT model in internet banking adoption context. Journal of Research in Interactive Marketing, 13(3), 411-435. doi:10.1108/ JRIM-02-2018-0032

Ringle, C. M., Wende, S., \& Becker, J.-M. (2015). SmartPLS 3. Boenningstedt: SmartPLS GmbH.

Robson, I. (2013). Women's leadership as narrative practice: Identifying "tent making", "dancing" and "orchestrating" in UK Early Years services. Gender in Management, 28(6), 338-358. doi:10.1108/GM-012013-0004

Saddam, A. K., \& Mansor, N. N. A. (2015). The Role of Recruitment and Selection Practices in the Original Performance of Iraqi Oil and Gas Sector: A Brief Literature Review. Review of European Studies, 7(11), 348. doi:10.5539/res.v7n11p348

Samar, R., \& Mazuri, A. G. (2019a). Does gamified elements influence on user's intention to adopt internet banking with integration of UTAUT and General Self-Confidence? International Journal of Business Excellence, $O(0), 394$. Advance online publication. doi:10.1504/IJBEX.2019.102835

Samar, R., \& Mazuri, A. G. (2019b). Integration of DeLone \& McLean and Self-Determination Theory in internet banking continuance intention context. International Journal of Accounting and Information Management, 27(3).

Samar, S., Ghani, M., \& Alnaser, F. (2017). Predicting customer's intentions to use internet banking: The role of technology acceptance model (TAM) in e-banking. Management Science Letters, 7(11), 513-524.

Sareen, P., \& Mishra, S. (2016). A study of talent management and its impact on performance of organizations. Journal of Business and Management, 18(12), 66-73.

Saviour, A. W., Kofi, A., Yao, B. D., \& Kafui, L.-A. (2017). The impact of effective recruitment and selection practice on organisational performance (a case study at University of Ghana). Global Journal of Management and Business Research.

Schroeder, H. (2012). The importance of human resource management in strategic sustainability: An art and science perspective. Journal of Environmental Sustainability, 2(2), 4.

Seniwoliba, J. (2015). Succession planning: Preparing the next generation workforce for the University for Development Studies. Academic Press.

Shah, N. (2011). A study of the relationship between organisational justice and employee readiness for change. Journal of Enterprise Information Management, 24(3), 224-236. doi:10.1108/17410391111122835

Sharif, A., \& Karim, M. (2017). Influence of job analysis program on employees: A study on selected companies of Bangladesh. International Journal of Scientific and Engineering Research, 8(5), 1221-1225.

Siguaw, J. A., Simpson, P. M., \& Enz, C. A. (2006). Conceptualizing innovation orientation: A framework for study and integration of innovation research. Journal of Product Innovation Management, 23(6), 556-574. doi:10.1111/j.1540-5885.2006.00224.x

Sternberg, R. J., \& Lubart, T. I. (1999). The concept of creativity: Prospects and paradigms. Handbook of Creativity, 1, 3-15.

Suthar, B., Chakravarthi, T. L., \& Pradhan, S. (2014). Impacts of job analysis on organizational performance: An inquiry on Indian public sector enterprises. Procedia Economics and Finance, 11, 166-181. doi:10.1016/ S2212-5671(14)00186-5 
Swaiess, M., \& Yamin, M. A. (2019). Investigating Employee creative performance with integration of DeLone and McLean Information system success model and Technology acceptance model: The moderating role of Creative self-efficacy. International Journal of Business Excellence. Advance online publication. doi:10.1504/ IJBEX.2019.10024168

Tierney, P., Farmer, S. M., \& Graen, G. B. (1999). An examination of leadership and employee creativity: The relevance of traits and relationships. Personnel Psychology, 52(3), 591-620. doi:10.1111/j.1744-6570.1999. tb00173.x

Trybou, J., Gemmel, P., Desmidt, S., \& Annemans, L. (2017). Fulfillment of administrative and professional obligations of hospitals and mission motivation of physicians. BMC Health Services Research, 17(1), 28. doi:10.1186/s12913-017-1990-0 PMID:28086876

Tufail, M. S., Bashir, M., \& Shoukat, N. (2017). Impact of job design on employee's organizational citizenship behavior and counterproductive work behavior in the banking sector of Faisalabad. City University Research Journal, 2017, 225-235.

Uddin, M. J., Luva, R. H., \& Hossian, S. M. M. (2013). Impact of organizational culture on employee performance and productivity: A case study of telecommunication sector in Bangladesh. International Journal of Business and Management, 8(2), 63.

Uzkurt, C., Kumar, R., Semih Kimzan, H., \& Eminoğlu, G. (2013). Role of innovation in the relationship between organizational culture and firm performance: A study of the banking sector in Turkey. European Journal of Innovation Management, 16(1), 92-117. doi:10.1108/14601061311292878

Vroom, V. R. (1964). Work and motivation. Academic Press.

Wang, C. L., \& Ahmed, P. K. (2004). The development and validation of the organisational innovativeness construct using confirmatory factor analysis. European Journal of Innovation Management, 7(4), 303-313. doi: $10.1108 / 14601060410565056$

Wang, S., \& Noe, R. A. (2010). Knowledge sharing: A review and directions for future research. Human Resource Management Review, 20(2), 115-131. doi:10.1016/j.hrmr.2009.10.001

Wu, C.-S., Tsai, L.-F., \& Wang, P.-W. (2011). Correlation between technological creativity, self efficacy and knowledge sharing among athletes. Academic Press.

Yamin, M. (2020). Examining the role of transformational leadership and entrepreneurial orientation on employee retention with moderating role of competitive advantage. Management Science Letters, 10(2), 313-326. doi:10.5267/j.msl.2019.8.039

Yamin, M. A. Y. (2020). Examining the effect of organisational innovation on employee creativity and firm performance: Moderating role of knowledge sharing between employee creativity and employee performance. International Journal of Business Innovation and Research, 22(3), 447-467. doi:10.1504/IJBIR.2020.108009

Yamin, M. A. Y. (2020). The Relationship between RIGHT Ethical Behavior Perspective, Demographic Factors, and BEST Ethical Performance. International Review of Management and Marketing, 10(1), 27-39. doi:10.32479/irmm.9100

Yamin, M. A. Y., \& Alyoubi, B. A. (2020). Adoption of telemedicine applications among saudi citizens during covid-19 pandemic: An alternative health delivery system. Journal of Infection and Public Health, 13(12), 1845-1855. Advance online publication. doi:10.1016/j.jiph.2020.10.017 PMID:33172819

Zhou, J., \& George, J. M. (2003). Awakening employee creativity: The role of leader emotional intelligence. The Leadership Quarterly, 14(4-5), 545-568. doi:10.1016/S1048-9843(03)00051-1

\footnotetext{
Jehad Saiyah Aiyash Bani- Hani has been promoted to Associate Professor in Business Administration in April, 2015. He published many articles in indexed journals with research interest in different topics such as Smart Operations Management, Quality and Strategic Management. Books' publications have also been one of his research interests; two books were significantly contributed to the fields of Operations Research \& Marketing Information System. Moreover, he has supervised more than 15 master theses in various interesting topics of management during the last ten years. Currently he is working in the Department of Health Services \& Hospital Management, College of Business, University of Jeddah in addition to his previous work experience in different Jordanian universities.
} 